\title{
FILSAFAT ILMU MANAJEMEN PENDIDIKAN ISLAM REKONTRUKSI KRITIS ISLAMISASI MANAJEMEN PENDIDIKAN ISLAM DALAM KONTEKS KEKINIAN
}

\author{
Muhammad Khaeron
}

Jurusan Hukum Keluarga Fakultas Syariah dan Ekonomi Islam IAIN Syekh Nurjati Cirebon khaeron.ak@gmail.com

\begin{abstract}
Abstrak
Ilmu dalam pandangan Islam adalah bagian penting dalam kehidupan manusia. Ia mesti dipelajari dan dimiliki oleh manusia termasuk dalam hal ini ilmu manajemen pendidikan. Dalam perspektif Islam, ilmu manajemen pendidikan mesti memuat prinsip dan nilai Islam yang dapat membimbing siswa menuju eksistensinya sendiri. Ilmu manajemen pendidikan konvensional, secara eksplisit tidak memuat makna yang relevan dengan prinsip dan nilai Islam. Hal ini sangat penting sebab manusia berperilaku dan bersikap senantiasa dibimbing oleh ilmu pengetahuan. Namun, secara implisit, ilmu manajemen pendidikan konvensional yang notabene dimunculkan di Barat, telah menggambarkan konsep manajemen yang dikembangkan Nabi Muhammad. Walaupun istilah yang digunakan tidak sejalan dengan Islam, namun dari isi arti telah selaras dengan prinsip dan nilai manajemen pendidikan Islam, yaitu produktivitas, mensejahterahkan, adanya sistem pahala dan dosa, memperhatikan efektifitas dan efisiensi, sumber daya manusia mesti berilmu, bertanggungjawab, mementingkan perencanaan, pengorganisasian, pelaksanaan, pengawasan, pelibatan sumber daya manusia, disiplin, adanya standar, dan memfokuskan pada standar moral dan etika pendidikan Islam.
\end{abstract}

Kata kunci : moral, etika, nilai, wahyu, sunnah

\section{A. Pendahuluan}

Seiring dengan perkembangan kajian filsafat ilmu, berdampak pula kepada perkembangan ilmu pengetahuan. Karena tingginya tradisi keilmuan dan terpenuhinya sarana penelitian khususnya di dunia Barat, hal demikian banyak terjadi. Kondisi tersebut tentunya menarik para cendekiawan dan pelajar dari banyak negara, terutama dari orang-orang Islam.

Salah satu ilmu pengetahuan yang cukup pesat berkembang ialah ilmu manajemen pendidikan. Kajian ilmu ini menjadi perhatian banyak pelajar yang konsern terhadap ilmu pendidikan.
Materi di dalamnya banyak berhubungan dengan perencanaan, pengkoordinasian, pengorganisasian, aktualisasian, pengawasan, dan evaluasi. Hal tersebut, dewasa ini sangatlah diperlukan pengelolaan lembaga pendidikan, khususnya umat Islam.

Keadaan ini tampaknya direspon oleh sejumlah perguruan tinggi Islam yang selanjutnya mendirikan program studi atau jurusan manajemen pendidikan Islam. Akan tetapi yang masih menjadi studi setelah itu ialah menjawab pertanyaan apa sajakah kurikulumnya? Sejumlah cendekiawan memperlihatkan bahwa mayoritas 
masih menginduk pada asal ilmu manajemen ini, yaitu ilmu-ilmu sekuler yang banyak dicetuskan di Barat. Tentunya ini bukan tanpa persoalan, sebab budaya negara tersebut berbeda dengan budaya umat Islam pada umumnya.

Dinamika ilmu manajemen pendidikan yang senantiasa berkembang sejalan dengan perubahan zaman. Ilmu manajemen pendidikan adalah salah satu bagian ilmu pengetahuan yang diciptakan, dikembangkan dan dimanfaatkan bagi kemajuan pendidikan Islam. Untuk itu, ilmu pengetahuan sudah banyak menyumbangkan bagi kemajuan peradaban manusia terutama dalam memenej suatu lembaga pendidikan.

Dalam hal ini semestinya sejumlah konsep dasar Islam diintegrasikan ke dalam ilmu pengetahuan apapun yang dipelajari oleh umat Islam, dalam arti lain ilmu pengetahuan tidak berlandaskan arti-arti dan ungkapanungkapan sekuler semata, tetapi juga ideologi (Azzam, 2000: 17; John, 2000: 35). Agar bisa dicapai konsep keutuhan ilmu pengetahuan, sejalan dengan ajaran-ajaran yang tertuang di dalam alQuran dan Hadits. Sebab, Islam dipercaya sebagai ajaran yang lengkap bagi semua aspek kehidupan, universal, dan rahmatan lil alamin untuk seluruh umat manusia. Sebagaimana firman Allah dalam Q.S. al-Ma'idah ayat 3 “...... Pada hari ini sudah Aku sempurnakan untukmu agamamu, dan sudah Aku cukupkan bagimu nikmat$\mathrm{Ku}$, dan sudah $\mathrm{Aku}$ relakan Islam itu menjadi agama bagimu".

Dengan demikian, ilmu pengetahuan sudah semestinya memuat prinsip-prinsip ajaran Islam. Sehingga secara jelas bisa mengarahkan dan membimbing manusia dalam mengembangkan dan menerapkan ilmu pengetahuan namun tetap dalam semangat ketauhidan.
Diantara kritik terhadap ilmu pengetahuan sekuler selama ini adalah pencarian dan pencapaian kepentingan organisasi semata. Hal ini tidak terlepas dari peran sempit akal, yang tidak terintegrasi dengan dzikir. Sebagaimana yang tertuang dalam Qur'an Surat Ali Imran ayat 190. Studi ini ditujukan untuk memberi kepercayaan mengenai ilmu pengetahuan yang tidak boleh mengesampingkan kebenaran ilahiah.

Sementara itu, ada yang menduga bahwa ilmu manajemen ditumbuh kembangkan di Dunia Barat, namun di lain pihak menjelaskan ilmu manajemen pendidikan bersumber dari peradaban Islam. Dunia Barat berpandangan bahwa tonggak lahir dan berkembangnya ilmu manajemen diawali pada masa revolusi industri. Perubahan ini ditinjau dari cara produksi barang yang dulunya hanya dibuat secara manual, tetapi selanjutnya berubah dengan penggunaan mesin produksi dan dilakukan secara besarbesaran. Sehingga memunculkan gagasan-gagasan untuk manajemen usaha produksi tidak melalui trial and error (Unyimadu, 1989: 209-218).

Dalam dunia Islam, sejumlah tokoh yang dianggap sebagai pemikir ilmu manajemen pendidikan, secara periode waktu diantaranya (1) Khulafa' al-Rashidin (632-661 $\quad$ M) yang membangun sistem manajemen pendidikan yang masih tetap sejalan dengan ajaran yang diterapkan pada masa Nabi Muhammad saw, khususnya mengenai sistem musyawarah. (2) AlFaraby (870-950 M) yang menciptakan konsep kerjasama yang baik mengenai komunitas masyarakat yang unggul. (3) Al-Mawardi $\quad(972 / 1058 \quad$ M) mengungkapkan pemikiran mengenai manajemen berasaskan petunjuk alQur'an dan Hadits yang diperlihatkan pada penguasa saat itu. (4) Al-Ghazali (1058-1111 M) menggagas pemikiran mengenai konsep manajemen yang 
memuat prinsip-prinsip keadilan. (5) Ibn Khaldun (1332-1395 M) sosiolog muslim yang menggagas pemikiran mengenai konsep perspektif sosial pada manajemen.

Secara umum prinsip manajemen pendidikan Islam yang diketengahkan ialah (1) mencegah manusia dari kerugian dan kekufuran; (2) selaras dengan hakikat penciptaan manusia; (3) mencari keridhaan Allah; (4) mendidik manusia menjadi beradab; (5) sejalan dengan tuntutan hak asasi manusia; (6) menggunakan pengetahuan dan ketrampilan melakukan kebaikan; dan (7) ditujukan bagi kebahagiaan dunia dan akhirat (al-falah).

Dengan demikian, terdapat perbedaan pendapat dalam melihat khususnya ilmu manajemen pendidikan dan umumnya ilmu pengetahuan itu sendiri. Ilmu-ilmu manajemen pendidikan yang berkembang dewasa ini memang tidak bisa semata-mata dinilai salah, namun harus adanya kajian kritis mengenai pemikiran ilmu manajemen pendidikan yang diklaim lahir di Barat itu. Sehingga, banyak temuan mengenai konsep dan ilmu manajemen pendidikan masa lalu bisa dilakukan kajian-kajian sejalan dengan nilai-nilai yang diajarkan oleh Islam itu sendiri. Pakar-pakar sejarah manajemen pendidikan berpandangan bahwa, dengan mengetahui apa yang terjadi atau apa yang menjadi pemikiran di masa lampau akan bisa memperkaya masa sekarang, dan juga sebagai panduan dalam memperkirakan masa yang akan datang (Baskara, 2013: 143144).

Memperhatikan berbagai konsep dan pemikiran mengenai ilmu-ilmu manajemen pendidikan pada masa lampau yang dikenal dengan istilah ilmu klasik, masa kini, dan menekankan konsep-konsep manajemen pendidikan yang berdasarkan Islam, maka mesti dilakukan kajian secara mendalam untuk mendapatkan titik temu antara konsep-konsep dan ilmu-ilmu manajemen pendidikan yang menjadi pemikiran tokoh-tokoh manajemen. Di waktu lampau sehingga saat ini dan tentunya juga memperhatikan zaman peradaban atau kejayaan Islam di masa itu.

Hal ini juga terlihat dalam disiplin ilmu dan kajian-kajian yang muncul darinya. Studi ini mengkaji mengenai urgensi islamisasi ilmu manajemen pendidikan, dimulai dari penjelasan mengenai kajian kritis atas penerapannya, sehingga tahap yang sudah ditemukan pioner-pioner dalam bidang islamisasi ilmu manajamen pendidikan.

\section{B. Metode Penelitian}

Jenis data dalam penelitian ini ialah data kualitatif karena berupa ungkapan para pemikir mengenai konsep dan ilmu manajemen pendidikan. Pendekatan yang digunakan adalah studi pustaka (library research). Dalam penelitian ini memakai dokumen berupa ensiklopedi, karya-karya monumental, dokumendokumen, otobiografi, dan yang berhubungan dengan masalah penelitian. Penelitian ini bertujuan untuk rekontruksi kritis dan mengkaji terhadap perkembangan konsep dan ilmu manajemen pendidikan. Merujuk al-Attas mengatakan bahwa tubuh ilmu pengetahuan mesti memuat nilai-nilai Islam apapun sumber ilmu dan bentuk ilmu pengetahuan itu direalisasikan.

Dalam penelitian ini sumber data yang dipakai ialah buku-buku yang membahas islamic science, buku-buku sejarah Rasulullah, buku-buku manajemen klasik, buku-buku manajemen modern, buku-buku manajemen dalam konteks Islam, dokumen ensiklopedia, dan lain-lain. Instrumen pengumpulan data ialah dokumen dan Focus Group Discussion (FGD). Analisis data 
dilakukan melalui pengumpulan data, reduksi data, display data, dan penyimpulan data.

\section{Perpestif Islam tentang Manajemen Pendidikan}

Manajemen pendidikan Islam bisa disebut sebagai suatu konsep yang berpijak pada hakekat penciptaan manusia itu sendiri sebagai khalifah di muka bumi. Sehingga eksistensi manusia ini berperan penting dalam mensukseskan organisasi (Palmer, 1997: 294-307) sebagai kewajiban dalam melaksanakan tanggungjawabnya. Dengan demikian, saat membahas konsep manajemen pendidikan tidak bisa dilepaskan dari perilaku manusia (Kondalkar, 2018: 5). Semua manajer mesti memiliki dan mengimplementasikan prinsip-prinsip ajaran Islam yang sejalan dengan konsep manajemen, yaitu musyawarah (syura), amanat (amanah), dan keadilan (al-'adl) (al-Munawar, 2004).

Manajemen pendidikan dalam perspektif Islam memang tidak secara nyata dijelaskan di dalam al-Qur'an mengenai konsep manajemen pendidikan. Namun, konsep manajemen bisa ditinjau pada kata "yudabbiru" yang bermakna bahwa Allah ialah mengatur, menetapkan dan mengurus berbagai urusan berkaitan dengan penciptaan alam semesta (Q.S. Yunus: 3). Kata yudabbiru dalam bahasa Arab bisa dimaknai dengan mengawal, melaksanakan, mengatur, mengurus, mengarahkan, dan mengendalikan.

Oleh karena itu, bisa dikatakan bahwa manajemen pendidikan dalam perspektif Islam, sesungguhnya sudah ada semenjak sejarah peradaban manusia. Konsep manajemen pendidikan dalam Islam sudah ada saat kelahiran Islam, yakni saat Nabi Muhammad s.a.w masih berdakwah di Mekah. Manajemen pendidikan Islam semakin berkembang saat beliau berhijrah ke Madinah dan membangun pemerintahan Islam yang pertama.

Dengan demikian, kajian manajemen pendidikan Islam dimulai sejak Nabi Muhammad diutus menjadi seorang Rasul, dengan alasan bahwa beliau ialah seorang pionir sistem manajemen pendidikan pada masa permulaan Islam, yang berkualitas dan cakap untuk menegakkan kalimat tauhid di muka bumi dalam syiar Islam. Rasulullah s.a.w ialah seorang yang layak dijadikan panutan sepanjang masa oleh setiap orang sebagai seorang manajer dan pemimpin.

Luasnya keteladanan Rasulullah saw meliputi setiap aspek kehidupan. Manfaat mempelajari sejarah Rasulullah saw ialah agar semua orang Islam mendapatkan gambaran me-ngenai hakekat Islam dengan paripurna, yang tercermin di dalam kehidupan Nabi Muhammad saw, setelah ia dipahami secara konsepsional sebagai hukum, kaidah, dan prinsip. Kajian sejarah Rasulullah saw hanyalah merupakan usaha aplikatif yang dimaksudkan untuk menjelaskan hakekat Islam secara holistik dalam keteladanannya yang tertinggi, Rasulullah saw.

Keteladan ini pada setiap spektrum kehidupan, khususnya dalam dunia pendidikan, sangat memerlukan figur pendidik dan tenaga kependidikan dalam manajemen pendidikan dan memperlakukan peserta didik sebagai organisma yang tumbuh dan harus diperhatikan dari masa ke masa. Sebab memang pendidikan semestinya adalah proses transformasi budi pekerti dan nilai tidak hanya transmisi pengetahuan dan data semata.

Sejarah menjelaskan bahwa Rasulullah saw sudah menanamkan kasih sayang dalam kepemimpinannya. Jelas, bagaimana cara beliau mendidik, berinteraksi, dan memimpin umatnya. Tidak mengherankan, kejayaan Islam pertama dipegang oleh para tokoh yang 
tidak diragukan lagi kemampuannya. Hamba sahaya seperti Salman al-Farisi yang sebelumnya hanya mengenal cara menanam dan merawat pohon kurma di Madinah dapat menjadi gubernur yang sukses di Persia. Bagaimana pengembala kambing seperti Abdullah bin Mas'ud dapat menjadi 'guru' dan ahli tafsir al-Qur'an. Demikian pula, Sosok 'preman' Umar bin Khattab yang berikutnya menjadi pimpinan negara yang sulit ditemukan tandingannya di waktu sekarang atau Khalid bin Walid menjadi sosok panglima perang dari hanya seorang 'jagoan kampung'.

Rasulullah saw ialah contoh yang baik dalam banyak segi kehidupan. Diantara dimensi pada keberhasilan Rasulullah saw dalam manajemen pendidikan Islam. Memang, beliau ialah anak yatim yang tidak memperoleh pendidikan formal yang mengajarkannya membaca menulis, akan tetapi beliau sangat memfokuskan pentingnya pendidikan bagi peningkatan mutu manusia. Beliau tidak pernah menerima pendidikan di lembaga-lembaga pendidikan Yunani yang diasuh oleh filosof-filosof, akan tetapi pemikirannya dapat merespon banyak permasalahan manusia.

Tidak ada manusia yang sedemikian baik bisa dicontoh sebab pada dirinya ada banyak sifat mulia. Selain itu, Rasulullah saw juga pernah mengalami banyak kondisi hidupnya. Beliau pernah mengalami hidup yang sulit sehingga bisa menjadi contoh untuk orang-orang yang sedang mengalami permasalahan hidup. Beliau pernah pula menjadi orang kaya, sehingga bisa menjadi contoh bagaimana semestinya memanfaatkan kekayaan. Beliau pernah menjadi pemimpin atau manajer di banyak bidang untuk kita bisa mencontoh manajerialnya.

Model manajemen pendidikan yang dilakukan oleh Nabi Muhammad memuat empat unsur penting, yakni: tauhid, ibadah atau amal shaleh, khalifah, dan kesuksesan. Untuk mendukung model manajemen pendidikan Islam yang baik, dalam peran manusia sebagai khalifah, Nabi Muhammad s.a.w melakukan tiga hal penting dalam kepimpinan Islam, yakni al-syura, keadilan, dan kebebasan berpendapat. Yang mana, dalam melaksanakannya mesti sejalan dengan lima sisi nilai-nilai Islam, yakni kewibawaan diri, peningkatan hubung-an, efektifitas kepimpinan, peningkatan moral melalui pengetahuan rohani, dan tata kelola yang beretika.

Untuk merealisasikan tujuan manajemen pendidikan Islam, yaitu alfalah berdasarkan paradigma tauhid sebagai filsafat manajemen pendidikan berdasarkan prinsip Islam, maka dalam melaksanakan fungsi-fungsi manajemen organisasi sudah seharusnya berasaskan pada amal ibadah dan kekhalifahan yang berpijak pada prinsip-prinsip ajaran Islam. Sehingga sistem manajemen pendidikan lebih bersifat menyeluruh, yakni terintegrasi antara proses manajemen lembaga dengan prinsip-prinsip ajaran Islam yang tidak boleh berubah kapanpun dan dimanapun.

Manajemen yang baik adalah manajemen yang dapat memenuhi sejumlah kriteria yaitu ciri, falsafah, dan profesionalisme. Untuk mewujudkan al-falah, tiga dimensi penting harus menjadi perhatian, yakni: ciri dan falsafah, sumber manusia dan alam, (3) profesionalisme (sistem dan amalan). Keunggulan filsafat dan nilai manajemen pendidikan Islam ialah sebab sumbernya, yakni al-Qur'an dan alSunah. Keduanya merujuk kepada nilai kemasyarakatan dan kemanusiaan serta teringrasi dalam satu ikatan yang erat.

Berdasarkan pada model manajemen pendidikan yang pernah diterapkan oleh Nabi Muhammad s.a.w 
tersebut, dan semangat islamisasi ilmu pengetahuan dan realisasi paradigma konsep manajemen versi Barat. Maka, harus ada pembahasan dan pemaknaan kembali mengenai konsep manajemen pendidikan Islam yang sudah dikembangkan Dunia Barat ke dalam konsep manajemen pendidikan yang berdasarkan prinsip-prinsip Islam. Setidaknya ada empat kepentingan pengkajian ulang tersebut sebagai bagian proses islamisasi ilmu pengetahuan, yakni kepentingan akidah, kepentingan kemanusiaan, kepentingan peradaban, dan kepentingan ilmiah. Empat kepentingan ini saling berkaitan satu dengan yang lain.

Manajemen pendidikan Islam, baik langsung ataupun tidak langsung, nilai-nilai yang mesti tertuang di dalam konsep manajemen yaitu (1) bermuara tauhid (Q.S. 2:21, 22, 255; Q.S. 112:14; Heri, 2018; Mawardiyanti, Indri, 2018), (2) keputusan berpijak pada musyawarah (syura) (Hafidhuddin dan Tanjung, 2003; al-Munawar, 2004; Naceur, 1994), (3) manajemen dilaksanakan dengan kumpulan (Naceur, 1994; Hafidhuddin dan Tanjung, 2003), (4) menetapkan arah tujuan organisasi yang mau dicapai, yang dinyatakan dengan jelas (Q.S. 2: 30; Q.S. 51: 56), (5) mempertimbangan kemaslahatan (mashlahah) manusia dan tercapainya al-falah dalam tujuan organisasi (Q.S. 21: 107; Q.S. 38: 26), (6) harus didasarkan pada prinsip jiwa yang adil ( $a d l$ ') (Q.S. 4: 58; Q.S. 5: 8; Q.S. 16: 90; Q.S. 38: 26), (7) bertanggungjawab (mas'uliyah) terhadap apa yang diamanahkan (Q.S. 5: 42; Q.S. 26: 215), (8) dalam menjalan manajemen mesti didokumenkan sebagai bukti dalam menjalankan amanah (Q.S. 45: 29; Hunger dan Wheelen, 2001; Muhaimin, 2006; Indrajit dan Djokopranoto, 2006; Raja Malik 2003a; Bryson 2004; Haim, Lamy, dan Glickman, 2005), (9) memperhatikan prinsip keseimbangan (tawazun) dalam semua ketetapan dan mendistribusikan sumber daya organisasi dengan efisien (Q.S. 45: 29; Hunger dan Wheelen, 2001; Bryson, 2004; Haim, Lamy, dan Glickman, 2005; Indrajit dan Djokopranoto, 2006; Muhaimin, 2006), (10) mempertimbangkan prinsip prioritas (awlawiyat) terhadap program-program yang lebih penting (Q.S. 2: 22; Q.S. 13: 3; Q.S. 15: 19; Q.S. 49: 13; Omar, 1996; Zainal, 1999; (11) memper-timbankan prinsip bertahap (tadaruuj) dalam implementasinya (Q.S. 4: 43; Q.S. 5: 90,91; Djamil, 1997); Antonio, 2007, (12) berpegang teguh prinsip bertawakal saat sudah melaksanakan pekerjaan (Q.S. 3: 159; Q.S. 5: 58; Q.S. 10: 84; Q.S. 18:.23; Q.S. 59: 18).

Berpijak pada penjelasan di atas, maka bisa difahami bahwa sesungguhnya konsep manajemen dalam perspektif Islam semestinya ada pada nilai-nilai dan prinsip-prinsip Islam yang mesti ada, baik secara langsung tercantum dalam konsepnya ataupun sebagai panduan oleh pelaksanapelaksana manajemen (manajer).

Berdasarkan penjelasan tersebut, maka bisa difahami bahwa konsep manajemen pendidikan berdasarkan prinsip Islam ialah:

"input organisasi atau proses mengelola sumber daya yang dilandasi oleh jiwa sebagai khalifah, beribadah dan berpedoman syariah untuk merealisasikan kebahagiaan dan kesejahteraan dunia dan akhirat (al-falah) bagi setiap umat manusia atau stakeholder yang diridhai Allah dengan berprinsip ketauhidan".

Dalam rangka merealisasikan tujuan organisasi dengan efektif, efisien, dan sistematik dibutuhkan tindakan melalui fungsi-fungsi manajemen, yaitu: "perencanaan, 
pengorganisasian, pengarahan, pengawasan dan feedback yang didasari oleh prinsip jiwa kepemimpinan Islam: berilmu, bekerjasama, bebas berpendapat, adil, musyawarah, dan jiwa persaudaraan".

Berpijak pasa penjelasan tersebut, skema konsep manajemen pendidikan Islam bisa divisualkan yaitu:

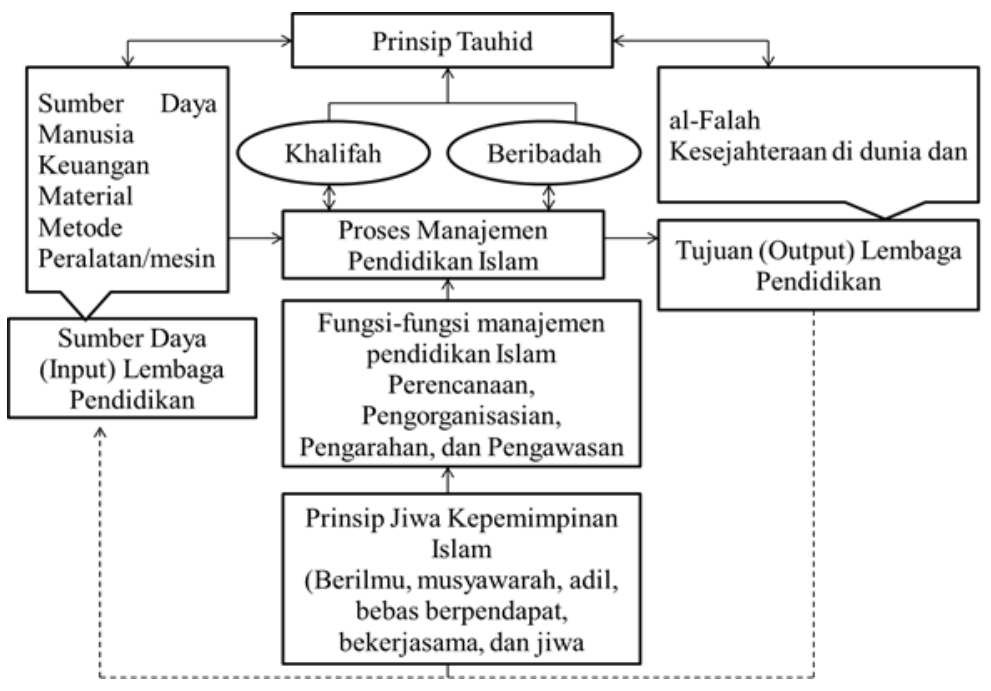

Gambar 2.2: Model Manajemen Pendidikan Islam

yaitu:

Gambar di atas bisa diuraikan

1. Kekayaan di dunia ini didapatkan dari sumber-sumber daya sebagai input lembaga pendidikan, yaitu: sumber manusia, informasi, mesin, metode, material, dan keuangan ialah menjadi hak mutlak Allah.

2. Manusia adalah khalifah diberi amanah untuk mengatur sumber daya yang ada di muka bumi dalam rangka ibadah kepada Allah, yang berpedoman pada ajaran Islam selaras dengan fitrah hakikat hidup manusia yang seluruhnya kembali kepada keberadaan Allah yakni prinsip Tauhid.

3. Guna pencapaian tujuan lembaga pendidikan yakni kebahagiaan dan kesejahteraan di dunia dan akhirat (al-falah), dibutuhkan keputusan pemanfaatan input organisasi atau sumber daya dengan efektif, efisien, dan sistematis melalui perencanaan, pengorganisasian, pengarahan dan pengawasan.
4. Untuk memperlancar proses dari fungsi manajemen pendidikan mesti dilandasi prinsip-prinsip kepemimpinan Islam yakni (1) manajer mesti berilmu; (2) penetapan keputusan penting dilaksanakan dengan musyawarah; (3) bersikap adil kepada setiap orang; (4) bebas berpendapat untuk menguatkan seseorang berusaha seoptimal mungkin untuk memperoleh pemahaman dalam berpandangan; (5) bekerjasama dengan setiap orang; dan (6) jiwa persaudaraan ditujukan untuk saling menghargai dan menghormati orang lain.

5. Apapun hasil daripada proses manajemen pendidikan senantiasa kembali kepada paradigma tauhid yakni melaksanakan urusan keduniaan berdasarkan kepada keimanan dan ketakwaan kepada Allah.

\section{Islamisasi Ilmu Manajemen Pendi- dikan}


Diantara kritikan terhadap ilmu manajemen pendidikan konvensional (sekular) adalah bagian dari ilmu pengetahuan, hanya dibatasi pada pencarian kompetensi dalam pencapaian tujuan lembaga pendidikan semata. Sebab hanya dilandasi oleh akal, dengan tidak memperhitungkan rahasia fungsi kehidupan manusia. Ilmu bukan kesatuan antara yang mengetahui (subyek ilmu) dengan yang diketahui (obyek ilmu), akan tetapi ia ialah kesatuan antara orang yang mengetahui dengan arti. Unsur-unsur arti ini dikonstruksi oleh jiwa dari obyekobyek yang diterima oleh indera saat jiwa menerima iluminasi dari Allah. Ini artinya unsur-unsur itu tidak ada dalam obyek-obyek yang ada (Daud, 1998: 149). Dengan kata lain, adanya makna ke dalam jiwa menunjukkan Allah adalah sumber pengetahuan, sedangkan hadirnya jiwa kepada makna berarti bahwa jiwa adalah penafsirnya (Attas, 2001: 133; 2007: 13 dan 39). Untuk itu, konsep dan ilmu manajemen adalah diantara bagian dari ilmu pengetahuan yang ada di dunia ini, yang diperkembangkan dan direalisasikan oleh Barat, maka sudah seharusnya pula mengindahkan semangat islamisasi ilmu pengetahuan.

Meskipun demikian manajemen pendidikan dalam perspektif Islam masih menerima dan mengakui kebenaran konsep manajemen sebagai ilmu pengetahuan dari Barat (Indra, 2009: 246). Dengan catatan tidak bertentangan dan tidak melemahkan dengan akidah Islam, maka bisa dipergunakan (Yusanto dan Widjajakusuma, 2002). Ibn Rushd (Omar, 2005) juga menjelaskan bahwa: Seandainya bangsa asing sudah menguasai ilmu tersebut (filsafat), maka adalah suatu kewajiban yang jelas terhadap kita (muslim) agar mempelajari dan mengambil manfaat dari apa yang sudah mereka kuasai, terlepas apakah bangsa tersebut beragama Islam ataupun tidak. Kita harus membaca buku-buku mereka, meneliti dan menilai apa saja yang dapat dijadikan teori. Seandainya apa yang dijelaskan itu benar, kita menerimanya, dan sebaliknya apabila keliru kita menolak.

Manajemen pendidikan dengan pendekatan sistem dan proses saat dipelajari pada prinsipnya sama, akan tetapi ada sejumlah perbedaan maksud dalam konsep itu sendiri. Seperti dijelaskan oleh Bartol, Martin, dan Kromkowski (2003) bahwa manajemen adalah proses pencapaian tujuan organisasi dengan mewujudkan empat tahapan penting, yaitu: perencanaan, pengorganisasian, pengarahan dan pengawasan. Mendasarkan kepada penjelasan Goerge dan Jones (2008) bahwa manajemen adalah proses merencanakan, mengorganisasikan, mengarahkan dan mengawasi sumber daya organisasi guna pencapaian tujuan organisasi secara efektif dan efisien. Adapun Stoner dan Wankel (1986) menyatakan bahwa manajemen adalah proses perancangan, pengorganisasian, memimpin dan pengontrolan upaya anggota organisasi serta memanfaatkan sumber-sumber organisasi untuk merealisasikan tujuan organisasi yang sudah ditentukan.

Disamping itu, ada yang menjelaskan manajemen sebagai suatu seni bekerja melalui peran serta orang lain. Konsep Barat mengenai manajemen tidak bersifat universal, ditentukan kepada siapa dan di mana merealisasikan konsep manajemen. Sebagaimana yang dijelaskan oleh Naceur (1994) bahwa sumbangan konsep manajemen konvensional ialah beragama, banyak yang disimpulkan dari studi empiris dalam kerangka budaya.

Dengan demikian, harus dilakukan penelaahan kembali melalui 
studi kritis terhadap sejumlah konsep dan ilmu manajemen pendidikan yang sudah berkembang sejauh ini. Sehingga lahir model dan konsep manajemen organisasi yang selaras dengan tradisi, nilai, dan budaya sekolah dan masyarakat. Yang mana, penduduk Indonesia sebagian besar ialah beragama Islam, maka semestinya pendekatan manajemen pendidikan yang diterapkan adalah pendekatan prinsip-prinsip dan nilai-nilai yang sejalan dengan Islam. Sejumlah kasus, seperti manajemen pendidikan di Jepang dan Korea Selatan menjadi berhasil, disebabkan oleh model dan konsep manajemen pendidikan yang sesuai dengan nilai-nilai yang terdapat di masyarakat setempat. Seperti dijelaskan oleh Gaby A. Mendoza (Omar, 1996) bahwa nilai-nilai dalam manajemen yang dipraktekkan oleh orang Asia dan Amerika ialah tidak sama, sebab kedua bangsa tersebut juga tidak sama.

Analisis terhadap konsep manajemen pendidikan dalam pandangan Islam, dapat menukil pandangan al-Faruqi bahwa dikotomi antara akal dan wahyu tidak dapat diterima oleh Islam. Menurutnya, pertentangan antara akal dan wahyu atau antara sains dan agama tidak bisa diakui dalam Islam (Omar, 2005). Disamping itu, al-Attas juga mengutarakan sejumlah konsep dasar Islam yang harus diintegrasikan ke dalam ilmu pengetahuan apapun yang dipelajari oleh orang Islam, sehingga Islamisasi mempunyai makna pelepasan ilmu pengetahuan dari asas-asas ideologi, dan arti-arti sekular (Nor, 2003). Pada persoalan tersebut, sistem manajemen pendidikan Islam bisa dinilai sebagai satu konsep yang sejalan dan berangkat dari kejadian manusia itu sendiri (Hassan, 1990; Mohamed, Ghani, dan Mansor, 2006). Manajemen pendidikan dalam persepektif Islam, secara jelas tidak diungkapkan secara spesifik dalam al-Quran mengenai konsep manajemen pendidikan itu sendiri. Walaupun begitu, definisi manajemen bisa ditinjau dari kata "yudabbiru" yang bermakna bahwa Allah ialah mengurus, menentukan, dan mengatur berbagai urusan yang berhubungan dengan alam raya ini dengan sempurna (Q.S. Yunus: 3). Menurut Buraey (1986) bahwa meskipun tidak ada kata secara spesifik mengenai manajemen pendidikan di dalam al-Quran, akan tetapi penggunaan kata yudabbiru dalam Bahasa Arab bisa dimaknai mengawal, mengatur, melaksanakan, mengurus, mengendalikan, dan mengarah. Berpijak pada tinjauan teoritik terhadap konsep dan ilmu manajemen pendidikan dalam perspektif Islam, maka prinsip, nilai, dan fungsi yang mesti ada dalam manajemen pendidikan baik secara eksplisit ataupun implisit diuraikan dalam tabel berikut.

Tabel 1. Prinsip, Nilai, dan Fungsi Manajemen Pendidikan Islam

\begin{tabular}{|l|l|}
\hline 1 & Tauhid \\
\hline 2 & Perencanaan \\
\hline 3 & Pengorganisasi \\
\hline 4 & Pengarahan \\
\hline 5 & Pengawasan \\
\hline 6 & Bekerjasama \\
\hline 7 & Bebas berpendapat \\
\hline 8 & Berilmu \\
\hline 9 & Bertawakal \\
\hline 10 & Amanah \\
\hline 11 & Bertahap (Tadarruj) \\
\hline 12 & Skala prioritas (awlawiyat) \\
\hline 13 & Kesejahteraan (al-falah) \\
\hline 14 & Keseimbangan (tawazun $)$ \\
\hline 15 & Bertangunggjawab (masuliyah) \\
\hline 16 & Keadilan(adl') \\
\hline 17 & Kemaslahatan (mashlahah) \\
\hline 18 & Musyawarah (syuura) \\
\hline
\end{tabular}

Definisi konsep dan ilmu manajemen pendidikan jika ditelaah fokusnya ialah manusia. Pada dasarnya 
kehidupan ini ialah mengurus mengenai manusia (Sidek, 1991). Dengan demikian, melihat peran manusia, manusia adalah perumus konsep dan ilmu manajemen pendidikan dan sasaran atas konsep dan ilmu manajemen pendidikan itu sendiri ialah juga manusia. Oleh karena itu, manusia memiliki peran kritikal dalam ilmu manajemen (Harahap, 1996), Allah menciptakan bumi untuk manusia, ia diberikan mandat untuk mengurus dan memakmurkan bumi.

Dalam perspektif Islam, bahwa konsep dan ilmu manajemen yang diformulasikan oleh Barat, saat dipelajari dari hijrah Nabi Muhammad saw dalam upaya beliau mensyiarkan agama Islam ke umat manusia, telah penuh arti secara tersurat dan tersirat yang menjelaskan konsep manajemen pendidikan yang berkembang sampai sekarang (Azmi, 2001). Dengan demikian, bagi manajer sekarang ini harus belajar kepada model manajemen dan kepimpinan yang sudah dilakukan oleh Nabi Muhammad, yakni model manajemen Islam (Naceur, 1994), agar bisa tercapai siswa yang cerdas dan berbudi pekerti luhur sebagai perwujudan komitmen daripada iman.

Pada hakekatnya pokok pikiran para pemikir konsep dan ilmu manajemen pendidikan secara implisit memiliki prinsip dan nilai Islam.

1. Aspek Eksplisitas

Tidak eksplisitnya prinsip dan nilai Islam dalam konsep dan ilmu yang dikembangkan pemikirpemikir, pada gilirannya melahirkan kritikan terhadap konsep dan ilmu manajemen pendidikan itu sendiri. Hal tersebut dikarenakan oleh sejumlah pendapat, diantaranya ialah pendapat al-Attas. Dia menjelaskan bahwa konsep dasar Islam yang mesti diintegrasikan ke dalam ilmu pengetahuan apapun yang dipelajari oleh kaum muslimin, sehingga islamisasi bermakna pembebasan ilmu pengetahuan dari interpretasi yang berdasarkan ideologi, ungkapan-ungkapan, dan arti-arti sekuler (Nor, 2003). Agar bisa dicapai konsep keutuhan ilmu pengetahuan, sejalan dengan semangat keterpaduan al-Qur'an dan al-Sunah.

Padahal, secara tegas al-Faruqi menjelaskan bahwa pelepasan akal dari wahyu tidak bisa diterima oleh Islam. Al-Faruqi mengatakan bahwa konflik antara akal dan wahyu atau antara agama dan ilmu pengetahuan tidak pernah diterima dalam Islam (Rahim, et al, 2018: 16; Omar, 2005). Islam sendiri, tidak saja menerima sensasi-logik, logika dan etika manusia, namun juga meyakini dan menerima kebenaran ilahi (transcendental) (Muhaimin, 2006). Ajaran-ajaran dari al-Qur'an yang disampaikan oleh Rasulullah s.a.w mengutarakan tidak pernah mendikotomikan aspek rohani dan materi dalam kehidupan (Ismail, 2000). Pemakaian akal bagi pengembangan keilmuan harus ada keseimbangan dengan iman, agar tidak bertentangan dengan akidah Islam (Baiquni, 1983). Oleh karena itu, ilmu mesti berdasarkan kepada wahyu Allah, tidak kepada persangkaan (Omar, M, 2005).

Hal ini dipertegas oleh gagasan al-Attas kembali yang mengutarakan bahwa, manusia bersikap dan bertindak senantiasa dibimbing dan dibina oleh suatu bentuk sains (Omar, 2003). Berpijak dari pandangan al-Attas tersebut, maka untuk muslim sangat penting untuk memiliki ilmu pengetahuan khususnya konsep dan ilmu manajemen yang sejalan dengan norma umat muslim sendiri, yakni sains yang berprinsipkan Islam. Meskipun ada sebagian pandangan 
yang menjelaskan bahwa ilmu pengetahuan bersifat netral dan universal, tidak hak milik suatu kelompok etnik tertentu saja (Omar, M, 2005). Artinya bisa dipakai oleh siapapun dan tidak memperhatikan siapa yang menciptakan.

Melalui pelepasan aspek-aspek ketuhanan pada konsep dan ilmu manajemen pendidikan Islam yang bersifat sekuler, maka terjadi kritik dari para pakar mengenai konsep dan ilmu manajemen pendidikan itu sendiri. Sejumlah contoh kritik, pertama yang dijelaskan Wan Liz Ozman Wan Omar (1996) bahwa manajemen pendidikan yang berdasarkan sekularisme hanya berorientasi pada persoalan dunia. Berbagai perilaku para siswa dan pendidik hanya dikaitkan dengan tujuan material saja dan tidak memperhitungkan nilai-nilai keridhaan ilahia dan non-kebendaan.

Kedua, dikarenakan oleh pemisahan praktek dan teori manajemen pendidikan dari agama (Azman, 2003). Ketiga kajian yang diterapkan oleh Rahardjo (1990) mengenai teori Weber yang sudah diakui oleh banyak orang, yang dinamakan dengan sistem manajemen birokrasi. Teori Weber menerangkan akan terdapatnya peraturan, pengaturan, hirarki, pembagian prosedur dan kerja yang didasarkan hanya pada logika birokrasi (bureaucracy rationalization) saja (Kalberg, 2010: 1145). Keempat, konsep manajemen konvensional hanyalah berkaitan dengan satu kelompok kegiatan yang meliputi perencanaan, pengorganisasi, motivasi dan pengawasan, khususnya lembaga yang terlibat dengan proses pendidikan dan komitmen untuk mengoptimalkannya bagi kepuasan konsumen (siswa), tanpa implementasi aspek rohani untuk meraih hasil manajemen pendidikan yang bersih dan diridhai oleh Allah (Harussani, 2005).

Kelima, manajemen pendidikan konvensional sebagai patokan yang dijadikan landasan yaitu kemanfaatan materi. Hal tersebut, menjerumuskan dan membingungkan. Sebab manajemen bisa dilihat sebagai alat dan kegiatan. Sebagai alat bisa dipakai dalam membantu memperlancar kegiatan hidup manusia, sehingga konsep manajemen pendidikan bisa disebut sebagai ilmu pengetahuan bersifat universal. Namun, saat ditinjau konsep manajemen pendidikan sebagai kegiatan bahwa yang dijadikan sebagai patokan ialah manfaat yang bersifat materi yang mau didapatkan, bukan lagi berdasarkan syariah (Widjajakusuma dan Yusanto, 2002).

2. Aspek Implisitas

Berlandaskan analisis kritis terhadap pokok gagasan para pemikir konsep dan ilmu manajemen pendidikan, pada hakekatnya secara implisit memiliki arti di balik konsep itu yakni adanya prinsip dan nilai Islam. Contoh, pokok pikiran yang menjelaskan bahwa produktivitas bisa meningkat manakala organisasi atau lembaga dapat dan mau memperhatikan kepentingan pegawai-pegawai atau anggota lembaga itu sendiri. Pernyataan kepentingan pegawai secara implisit sejalan dengan prinsip kemaslahatan (mashlahah).

Contoh lain, pokok pikiran yang menjelaskan bahwa pekerjaan mesti dilandasi oleh ilmu pengetahuan, dan lain-lain. Dengan demikian, ilmu harus dimiliki, dihayati, difahami, dan dipraktekkan oleh semua orang. Hal ini telah tersurat dalam al-Qur'an Surat al- 
'Ankabut ayat ke-43, yang bermakna "Dan perumpamaan-perumpamaan ini Kami buat bagi manusia; dan tidak ada yang memahaminya melainkan orang-orang yang berilmu". Allah sendiri sudah menjanjikan kepada orang-orang yang beriman dan berilmu akan menaikkan beberapa tingkat atau derajat. Hal ini difirmankan Allah dalam Qur'an Surat al-Mujadilah ayat 11 yang artinya: "Allah akan meninggikan orang-orang yang beriman di antara kamu dan orangorang yang diberikan ilmu pengetahuan beberapa derajat".

Oleh karena itu, ilmu pengetahuan sudah memberi kontribusi yang besar terhadap kemajuan tamadun dan pemikiran manusia terutama dalam mengelola suatu lembaga pendidikan. Bagi orang-orang Islam, tanpa mempunyai ilmu sulit untuk bisa memahami sesuatu. Pokok pikiran dari contoh lain, memiliki arti pelibatan pegawai dalam sejumlah keputusan penting dan pemberian sistem reward (pahala/ganjaran) bagi mereka yang berprestasi. Secara implisit ada prinsip dalam menerapkan manajemen pendidikan yakni prinsip musyawarah (assyura). Syura adalah diantara ciri konsep manajemen pendidikan Islam.

Syura ialah perbincangan dengan sejumlah orang untuk memecahkan persoalan atau membuat suatu kesepakatan. Arti lain, Syura berarti hendaknya seseorang tidak hanya mementingkan pendapatnya sendiri (ego) dalam memecahkan masalah yang membutuhkan kesepakatan bersama dari pemikiran yang lain. Karena pandangan dua orang atau lebih akan sangat mendekati kebenaran daripada pendapat seorang diri.
Dalam al-Qur'an menjelaskan syura (bermusyawarah) sebagai suatu prinsip yang mengelola kehidupan masyarakat daripada suatu sistem yang dikelola secara spesifik. Allah sudah menjadikan syura sebagai upaya penting dalam menetapkan suatu keputusan. Sebagaimana firman Allah dalam alQur'an Surat Ali Imran ayat 159 yang berarti “...... dan bermusyawarahlah dengan mereka dalam urusan itu. Lalu jika kamu sudah membulatkan tekad, maka bertawakallah kepada Allah. Sesungguhnya Allah menyenangi orang-orang yang bertawakal kepada-Nya". Demikan pula dengan firman Allah dalam al-Qur'an Surat al-Syura ayat 38, yang berarti "sedang urusan mereka (diputuskan) dengan musyawarah antara mereka; dan mereka menafkahkan sebagian dari rezeki yang Kami berikan kepada mereka".

Oleh karena itu, syura dipandang sebagai sebuah konsep dan sekaligus prinsip. Syura sebagai konsep, bahwa pertimbangan kumpulan (collective deliberation) lebih mungkin memunculkan hasil yang adil dan logis untuk kebaikan bersama daripada pertimbangan pribadi. Hal ini didasarkan alasan bahwa pertimbangan mayoritas cenderung lebih tepat dan komprehensif dibandingkan penilaian minoritas. Syura sebagai prinsip, bahwa setiap orang mempunyai hak, kewajiban dan tanggungjawab yang sama (Mohiuddin dan Islam, 2016: 85).

Disamping itu, syura sudah menjadi budaya selama kepimpinan Nabi Muhammad dan sesudah kepimpinan beliau. Tidak ada keputusan yang lebih baik tanpa perundingan (Naceur, 1994). Nabi Muhammad selalu bermusyawarah 
dengan sahabat-sahabatnya dalam sejumlah persoalan, khususnya dalam urusan pemerintahan dan keduniaan. Contoh, pada perjanjian damai Hudaibiyah, perang Badar, perang Uhud, dan keputusan lain.

Sehingga, dari banyak pokok pikiran konsep dan ilmu manajemen pendidikan yang sudah dikembangkan oleh pemikir-pemikir tersebut, secara implisit telah memuat prinsip dan nilai Islam walaupun tidak secara maksimal. Ketidak implisitnya prinsip dan nilai Islam dalam kandungan konsep dan ilmu manajemen pendidikan tidak lain dikarenakan oleh faktor manusia itu sendiri, seperti faktor: nilai, kefahaman, budaya, dan agama yang mereka praktekkan serta tahapan pencapaian akademik yang dimiliki (Omar, M., 2005), contohnya saat seseorang memiliki kefahaman, budaya, dan agama berprinsipkan nilai "X", maka dalam memformulasikan, merealisasikan dan mempraktekkan ilmu pengetahuan tidak terikat dengan prinsip nilai " $X$ " tersebut. Sehingga ditentukan oleh pengalaman peribadi individu (Muliawan, 2005).

3. Perbandingan Kajian Kritis Ilmu dan Konsep Manajemen Pendidikan

Berpijak pada hasil studi kritis sebagaimana telah dijelaskan, maka bisa dinyatakan sejumlah perbedaan antara konsep dan ilmu manajemen pendidikan yang merupakan kontribusi pemikir-pemikir yang diperkirakan dari Barat, dengan konsep manajemen pendidikan Islam.

Tabel 2.

Perbandingan Konsep Manajemen Pendidikan Konvensional dengan Manajemen Pendidikan Islam

\begin{tabular}{|c|c|c|c|}
\hline No & Elemen & $\begin{array}{l}\text { Konsep Manajemen Pendidikan } \\
\text { Konvensional }\end{array}$ & Konsep Manajemen Pendidikan Islam \\
\hline 1 & Dasar & $\begin{array}{ll}\text { a. } & \text { Pandangan hidup } \\
\text { materialistik kedunian. } & \\
\text { b. } & \text { Konsep utilitarianisme. }\end{array}$ & $\begin{array}{l}\text { a. Paradigma tauhid. } \\
\text { b. Keseimbangan antara dunia dan } \\
\text { akherat. }\end{array}$ \\
\hline 2 & $\begin{array}{l}\text { Tujuan } \\
\text { organisasi }\end{array}$ & $\begin{array}{l}\text { Memaksimalkan keuntungan } \\
\text { Kesuksesan untuk diri, lembaga } \\
\text { Pendidikan, atau negara. }\end{array}$ & $\begin{array}{l}\text { a. Keuntungan dengan tanggungjawab } \\
\text { sosial. } \\
\text { b. Kesuksesan bukan saja untuk diri } \\
\text { sendiri, organisasi, atau negara, } \\
\text { namun untuk umat, kemajuan } \\
\text { peradaban Islam semuanya } \\
\text { (holistic). }\end{array}$ \\
\hline 3 & Model & $\begin{array}{l}\text { Model manajemen pendidikan } \\
\text { beragam tergantung pada } \\
\text { individu, lembaga, dan kondisi. } \\
\text { Ide-ide manajemen pendidikan } \\
\text { ialah inovatif dan kreatif. }\end{array}$ & $\begin{array}{l}\text { Syura sebagai model manajemen } \\
\text { pendidikan yang abadi. Unsur-unsur } \\
\text { luar dalam manajemen pendidikan } \\
\text { bisa diselaraskan dengan Islam } \\
\text { (adaptable). }\end{array}$ \\
\hline 4 & Fungsi individu & $\begin{array}{l}\text { Mendedikasikan diri } \begin{array}{r}\text { kepada } \\
\text { pimpinan dan } \\
\text { pendidikan }\end{array} \\
\end{array}$ & $\begin{array}{l}\text { Penghambaan diri kepada Allah swt } \\
\text { sebagai khalifah }\end{array}$ \\
\hline 5 & $\begin{array}{l}\text { Penghargaan } \\
\text { (reward) }\end{array}$ & $\begin{array}{lll}\text { Penghargaan } & \text { lahiriah } & \text { dan } \\
\text { jangka pendek } & & \\
\end{array}$ & $\begin{array}{l}\text { Penghargaan dari segi pahala dan } \\
\text { dosa, bersifat jasmani dan rohani }\end{array}$ \\
\hline 6 & Filosofi kerja & $\begin{array}{l}\text { Kerja berdasarkan kepada } \\
\text { konsep faham material dan } \\
\text { kerja untuk kehidupan dunia } \\
\text { semata serta kerja untuk }\end{array}$ & $\begin{array}{l}\text { Kerja didasarkan pada niat dan } \\
\text { keikhlasan bekerja dan ibadah }\end{array}$ \\
\hline
\end{tabular}




\begin{tabular}{|c|c|c|c|}
\hline & & kepuasan diri & \\
\hline 7 & Motivasi & $\begin{array}{l}\text { Guna memperoleh pujian } \\
\text { atasan, kepuasan diri (self } \\
\text { actualization), dan penghargaan } \\
\text { jangka pendek berbentuk } \\
\text { kebendan }\end{array}$ & $\begin{array}{l}\text { Guna memperoleh keridhaan Allah } \\
\text { swt disamping merespon tuntutan } \\
\text { atasan }\end{array}$ \\
\hline 88 & Ukuran prestasi & Satu dimensi yakni ekonomi & $\begin{array}{l}\text { Disamping dimensi ekonomi juga } \\
\text { tanggungjawab sosial dan kerohanian. }\end{array}$ \\
\hline 9 & Ciri-ciri & $\begin{array}{l}\text { a. Nilai-nilai boleh berubah. } \\
\text { b. Tidak ada konsep al-falah } \\
\text { dan al-fasad. } \\
\text { c. Konsep baik dan buruk } \\
\text { adalah relatif. } \\
\text { d. Pemikiran dan metodologi } \\
\text { dan manajemen pendidikan } \\
\text { berdasarkan kepada idea } \\
\text { saintifik dan rasionalisme } \\
\text { manusia. } \\
\text { e. Budaya kerja yang bisa } \\
\text { berubah-ubah mengikat } \\
\text { norma dan nilai masyarakat } \\
\text { yang berubah. } \\
\text { f. Pembinaan akhlak tidak } \\
\text { terdapat dalam konsep. } \\
\text { g. Sistem manajemen } \\
\text { pendidikan yang terpisah } \\
\text { dengan alam sekitar terutama } \\
\text { yang berhubungan norma- } \\
\text { norma dan nilai-nilai } \\
\text { masyarakat. } \\
\text { h. Konsep a manajemen } \\
\text { pendidikan yang tidak } \\
\text { memiliki ikatan keselarasan } \\
\text { yang kukuh. } \\
\text { i. Tidak ada hubungan dengan } \\
\text { hukum-hukum keagamaan } \\
\text { dalam praktek manajemen } \\
\text { pendidikan, perencanaan, } \\
\text { pelaksanaan, dan proses } \\
\text { menyusun keputusan. }\end{array}$ & $\begin{array}{l}\text { a. Nilai-nilai mutlak dan nilai-nilai } \\
\text { universal. } \\
\text { b. Menegakkan al-falah } \\
\text { menentang al-fasad. } \\
\text { c. Konsep baik dan buruk berdasarkan } \\
\text { pada wahyu. } \\
\text { d. Pemikiran dan metodologi } \\
\text { manajemen pendidikan berdasarkan } \\
\text { kepada al-Qur'an dan al-Sunnah, } \\
\text { disamping sumber ijtimak, ijtihad, } \\
\text { dan lain-lain. } \\
\text { e. Budaya kerja berdasarkan pada } \\
\text { etika Islam, namun luwes dan } \\
\text { dinamis. } \\
\text { f. Fokus kepada pembinaan pribadi } \\
\text { dan akhlak. } \\
\text { g. Syumul dan menyeluruh dengan } \\
\text { mengambil faktor sistem nilai, } \\
\text { budaya, politik, ekonomi, dan sosial } \\
\text { dalam suatu masyarakat. } \\
\text { h. Konsep yang mengintegrasikan } \\
\text { pembangunan manusia melalui } \\
\text { pembinaan intelektual, jasmani, } \\
\text { rohani, dan emosi. } \\
\text { i. Terikat dengan hukum-hukum agama } \\
\text { jika menyusun keputusan seperti } \\
\text { halal, haram, sunah, wajib, makruh } \\
\text { termasuk siyasah syariah. }\end{array}$ \\
\hline
\end{tabular}

Sumber: diolah dari Wan Liz Ozman (1996)

Oleh karena itu, sebagai umat Islam, patut mengikuti budaya manajemen pendidikan yang sudah dikembangkan oleh Nabi Muhammad dan sahabat-sahabatnya (Naceur, 1994), yakni: (1) budaya percaya kepada wujudnya satu Tuhan yakni Allah SWT; (2) budaya percaya kepada hari akhir yang mereka akan dihadapkan ganjaran dan hukuman (pahala dan dosa); (3) dalam urusan keduniaan memakai budaya dialog; (4) budaya partisipasi melalui musyawarah, nasehat dan amar ma'ruf nahi mungkar; dan (5) budaya pembagian tugas.

\section{E. Kesimpulan}

$$
\begin{aligned}
& \text { Ilmu pengetahuan tidak terlepas } \\
& \text { nilai tergantung siapa yang } \\
& \text { memformulasikan dan mengembangkan } \\
& \text { ilmu pengetahuan. Pada kenyataannya, } \\
& \text { ilmu pengetahuan yang berkembang } \\
& \text { sekarang ialah bentuk pengasingan dan } \\
& \text { dikotomi ilmu pengetahuan. Dalam } \\
& \text { pokok-pokok pikiran pemikir-pemikir }
\end{aligned}
$$


konsep dan ilmu manajemen pendidikan belum dijumlah prinsip dan nilai Islam yang secara eksplisit terkandung dalam konsep dan ilmu manajemen pendidikan yang selama ini ada. Namun, secara implisit sebenarnya telah memuat arti sebagaimana prinsip dan nilai Islam. Sehingga ada kesan, bahwa konsep dan ilmu manajemen pendidikan yang dikembangkan oleh pemikir-pemikir manajemen pendidikan, konon dari Barat, hanya ditujukan pada aspek materi sematamata. Konsep manajemen pendidikan Islam mesti menekankan pada nilainilai humanis untuk kesejahteraan menuju tercapainya al-falah bagi semua peserta didik.

\section{Daftar Pustaka}

Antonio, Muhammad Syafii. 2007. The Super Leader Super Manager. Jakarta: Tazkia multimedia \& proLm Centre.

Attas, Syed Muhammad Naquib al-, 2001. Prolegomena to the Metaphysics of Islam, Kuala Lumpur: International Institute of Islamic Thought and Civilization (ISTAC). . 2007. Tinjauan Ringkas Peri Ilmu dan Pandangan Alam. Pulau Pinang: Penerbit Universiti Sains Malysia.

Azman, Che Omar. 2003. Pengurusan di Malaysia dari Perspektif Islam. Kuala Lumpur: Dewan Bahasa dan Pustaka

Baiquni, A. 1983. Islam dan Ilmu Pengetahuan Modern. Jakarta: Pustaka.

Bartol, Kathryn M., David C. Martin, Julie A. Kromkowski. 2003. "Leadership and the Glass Ceiling: Gender and Ethnic Group Influences on Leader Behaviors at Middle and Executive Managerial Levels," Journal of
Leadership \& Organizational Studies. Vol. 9, No. 3. 8-19.

Bryson, John M. 2004. What to do when stakeholders matter: stakeholder identification and analysis techniques. Public Management Review 6 (1) pp.21-53, London: Routledge.

Buraey, al-. 1986. Administrative Development: An Islamic Perspective by Al-Buraey. London, United Kingdom: Routledge.

Daud, Wan Mohd Wan. 1998. Filsafat dan Praktik Pendidikan Islam Syed $M$. Naquib al-Attas. Bandung: Mizan.

Djamil, Fathurrahman. 1997. Filsafat Hukum Islam. Jakarta: Logos Wacana Ilmu.

George, Jennifer M. dan Gareth R. Jones. 2008. Understanding and Managing Organizational Behavior. New Jersey: Pearson Education, Inc.

Hafidhuddin, Didin, dan Hendri Tanjung. 2003. Manajemen Syariah Dalam Praktik. Jakarta: Gema Insani Press.

Haim, Bar-, Lamy, dan Glickman. 2005. Attentional bias in anxiety: a behavioral and ERP study. Brain Cogn. 59(1):11-22.

Harahap, Sofyan Syafri. 1996. Manajemen Masjid: suatu Pendekatan Teoritis dan Organisatoris. Jakarta: Dana Bhakti Prima Yasa.

Hassan, Mohd. Affandi. 1990. Pura Bujangga. Kuala Lampur: Dewan Bahasa dan Pustaka, Kementerian Pendidikan Malaysia.

Heri, Totong. 2018. "Manajemen Pendidikan Islam Berbasis Tauhid”. Rausyan Fikr. Vol. 14 No. 1.

Hunger, J. David, dan Thomas L. Wheelen. 2001. Essentials of Strategic Management. Upper Saddle River, New Jersey, AmerikaPrentice Hall.

Harussani, Haji Zakaria. 2005. Nilai Murni Teras Pengurusan Cemerlang. Kertas Kerjas. Seminar Pengurusan Cemerlang II. Kemahiran 
Pengurusan Asa Keutuhan Organisasi. 29-31 Juli 2005.

Indra, Hasbi. 2009. "Pandangan Islam tentang Ilmu Pengetahuan dan Refleksinya terhadap Aktivitas Pendidikan Sians di Dunia Muslim," dalam MIQOT, Vol. XXXIII No. 2 Juli-Desember 2009. 245-260.

Indrajit, R. Eko dan Djokopranoto, R. 2006. Manajemen Perguruan Tinggi Modern. Yogyakarta: C.V. Andi Offset.

Ismail, Nor. 2000. Kepemimpinan Nabi Muhammad SAW: Pengurusan Altrustik Model Ikutan Sepanjang Masa, Perbandingan Silang dengan Kepemimpinan dan Pengurusan Semasa. Kuala Lumpur: Utusan Publications \& Distributions Sdn. Bhd.

Kalberg, Stephen. 2010. "Max Weber's Types of Rationality: Cornerstones for the Analysis of Rationalization Processes in History", American Journal of Sociology. Volume 85 Number 5. 1145-1179.

Kajeng, Baskara. 2013. "Lembaga Keuangan Mikro di Indonesia", dalam Jurnal Buleting studi Ekonomi, Vol.18, No.2.

Keane, John. 2000. "The Limits of Secularism," dalam Islam and Secularism in the Middle East, diedit oleh Jon L. Espasito dan Azzam Tamimi. 29-37. New York: New York University Press.

Kondalkar, V.G. 2018. Organizational Behaviour. New Delhi: New Age International.

Muhaimin. 2006. Nuansa Baru Pendidikan Islam: Mungurai Benang Kusut Dunia Pendidikan. Jakarta: PT Raja Grafindo Persada.

Muliawan, Ungguh Jasa. 2005. Pendidikan Islam Integrative: Upaya Mengintegrasikan Kembali Dikotomi dan Pendidikan Islam. Yogyakarta: Pustaka Pelajar.
Munawar, Said Agil Husin al-. 2004. alQur'an Membangun Tradisi Kesalehan Hakiki.

Mawardiyanti, Indri. 2018. Manajemen Kurikulum Berbasis Tauhid: Studi Kasus di SMP al-Rohmah Putir Boarding School Malang. Tesis. Malang: Program Pascasarjana Universitas Muhammadiyah.

Mohamed, Hasan al-Banna, Mumin Abd. Ghani, dan Fadillah Mansor. 2006. Dimensi Pengurusan Islam: Mengurus Kerja dan Mengurus Modal Insan. Kuala Lumpur, Selangor, Malaysia: Akademi Pengajian Islam, Universiti Malaya.

Mohiuddin, Md Golam, dan Mohammad Muzahidul Islam. 2016. "Decision Making Style in Islam: A Study of Superiority of Shura (Participative Management) and Examples from Early Era of Islam," dalam European Journal of Business and Management. Vol.8, No.4. 79-88.

Naceur, Jabnoun. 1994. Islam and Management. Kuala Lumpur: Institut Kajian Dasar (IKD).

Nor, Wan Asna Wan Mohd. 2003. Filsafat dan Praktik Pendidikan Islam. Syed M. Naquib Al-Attas. Bandung: Mizan Pustaka.

Omar, Mohd. Nasir. 2005. Gagasan Islamisasi Ilmu. Kuala Lumpur, Malaysia: Utusan Publications.

Omar, Wan Liz Ozman Wan. 1996. Pengurusan Islam Abad ke-21: Revolusi Pengurusan Untuk Keunggulan Sektor Awam dan Korporat. Kuala Lumpur: Utusan Publications \& Distributors Sdn. Bhd.

Ozman, Wan Liz, dan Wan Omar. 1996. Pengurusan Islam Abad ke-21: Revolusi Pengurusan untuk Keunggulan Sektor Awam dan Korporat. Kuala Lumpur: Utusan Publications \& Distributors Sd. Bhd.

Palmer, Joy. 1997. "The Human Organization". Journal of 
Knowledge Management, Vol. 1 Issue: 4, 294-307.

Rahardjo, M. Dawam, 1990. Etika Ekonomi dan Manajemen. Yogyakarta: Tiara Wacana.

Rahim, Adibah Abdul, Zuraidah Kamaruddin, dan Amilah Awang Abdul Rahman. 2018. "Al-Faruqi's Views on Selected Topics of Ilm alKalam," dalam International Journal of Islamic Thought. Vol. 13. Juni. 15-23.

Sidek, Mohd. Shahar. 1991. Pengurusan Masjid dan Masalah Semasa yang Dihadapi: Administration of Mosques and Current Problems Faced.

Stoner, James Arthur Finch, dan Charles Wankel. 1986. Management. Jilid 2. Upper Saddle River, New Jersey, United States: Prentice-Hall International.

Tamimi, Azzam. 2000. "The Origins of Arab Secularism," dalam Islam and Secularism in the Middle East, diedit oleh Jon L. Espasito dan Azzam Tamimi. 13-28. New York: New York University Press.
Unyimadu, Stephenson O. 1989. "Management and industrial revolution in Europe, United States of America and Japan". Engineering Management International. Volume 5, Issue 3, 209-218.

Widjajakususma, M. Karebet \& Yusanto, M. Ismail. 2002. Pengantar Manajemen Syari'ah. Jakarta: Khairul Bayan.

Yusanto, Muhammad Ismail, dan Muhammad Karebet Widjajakusuma. 2002. Menggagas bisnis Islami. Jakarta: Gema Insani Press.

Zainal, Abidin Mohamed. 1999. "Perancang Strategik dan Industri Pendidikan". Zainal Abidin Mohamde (penyt.). Pengurusan Strategik di Sektor Pendidikan. Serdang: Universiti Putra Malaysia. $1-30$. 